\title{
Estrategias narrativas y estéticas en el paso del cortometraje al largometraje: análisis del caso de Paula Ortiz
}

\author{
MHCJ no 7 | Año 2016 \\ Artículo no 18 (90) \\ Páginas 419 a 441 \\ mhjournal.org
}

\author{
Ignacio Lasierra Pinto| ilasierra@usj.es \\ Joseba Bonaut Iriarte| jbonaut@usj.es \\ Universidad San Jorge
}

\begin{abstract}
Palabras clave
Cine; cortometraje; estética; narrativa; Paula Ortiz.

Sumario

1.1. La naturaleza del cortometraje como obra cinematográfica. 1.2. El concepto de estilo 2. Metodologia 2.1. Propuesta metodológica 3. Resultados 3.1. Uso recurrente de los mismos actores a lo largo de toda la filmografía. 3.2. Presencia de prólogos y epílogos como elementos estructurales del relato. 3.3 Abundancia de recursos expresivos literarios a través de los diálogos de los personajes. 3.4

"Cosificación" de los conflictos y representación del estado anímico de los personajes a través de los objetos. 3.5 Insistencia en la utilización cámara lenta y de las secuencias elaboradas de montaje como recursos expresivos y potenciación de los elementos sonoros para transmitir emociones. 3.6 Introducción de un espacio onírico para explorar las emociones de los personajes. 3.7 Búsqueda de lugares comunes: utilización del espejo y del entorno natural. 4. Discusión y conclusiones 5 Bibliografía
\end{abstract}

filmico (2005).

\section{Resumen}

Muchos autores consideran al cortometraje como un medio para poder introducirse en la industria del cine y realizar, de este modo, piezas de larga duración. Existe otra corriente de opinión que considera a los cortometrajes como un género en sí mismo, con sus particularidades propias y que no tiene que limitarse a ser una pequeña pieza que muestre un potencial talento cinematográfico. Al margen de estas consideraciones, sí que es posible identificar en los cortometrajes inquietudes estéticas y narrativas que marcan (o pueden marcar) la trayectoria fílmica de un director.

El objetivo de esta comunicación es analizar las estrategias narrativas y estéticas utilizadas por una directora de éxito y con un marcado sello personal, Paula Ortiz (Zaragoza, 1979), en sus cortometrajes: El rostro de Ido (2003), Fotos de familia (2005) y El bueco de Tristán Boj (2008). Posteriormente, se compararán dichas estrategias con las utilizadas en sus dos largometrajes de ficción: De tu ventana a la mía (2011) y La Novia (2015).

El análisis narrativo y estético se realizará tomando los guiones originales de las obras citadas, así cómo los montajes originales de las películas estrenadas en festivales y salas cinematográficas.

Por último, como método de análisis se utilizará el propuesto por Vanoye y Goliot-Lété en su obra Précis d'analyse filmique (1992), y retomado por Tarín y Marzal en su texto Una propuesta metodológica para el análisis del texto

\section{Forma de citar este artículo en las bibliografías}

Ignacio Lasierra Pinto y Joseba Bonaut Iriarte (2016): "Estrategias narrativas y estéticas en el paso del cortometraje al largometraje: análisis del caso de Paula Ortiz”, en Miguel Hernández Communication Journal, nº 7 , páginas 419 a 441. Universidad Miguel Hernández, UMH (Elche-Alicante). Recuperado el __ de ___ de 20_ de: @ink del artículo en mhjournal.org] 


\section{Narrative and aesthetic strategies in the passage from the short film to the feature film: analysis of the case of Paula Ortiz}

\author{
MHCJ no 7 | Año 2016 \\ Artículo no 18 (90) \\ Páginas 419 a 441 \\ mhjournal.org
}

\author{
Ignacio Lasierra Pinto|ilasierra@usj.es \\ Joseba Bonaut Iriarte|jbonaut@usj.es \\ Universidad San Jorge
}

Keywords

Cinema; short film; aesthetics; film narrative; Paula Ortiz

Summary

1.1. The nature of the short film as a cinematographic work. 1.2. The Concept of Style 2. Methodology 2.1. Methodological proposal 3. Results 3.1. Recurrent use of the same actors throughout the film. 3.2. Presence of prologues and epilogues as structural elements of the story. 3.3 Abundance of expressive literary resources through the dialogues of the characters. 3.4 "Cosification" of conflicts and representation of the mood of the characters through the objects. 3.5 Insist on the use of slow motion and elaborate sequences of assembly as expressive resources and enhancement of the sound elements to convey emotions. 3.6 Introduction of a dream space to explore the emotions of the characters. 3.7 Search for common places: use of the mirror and the natural environment. 4. Discussion and conclusions 5 Bibliography

\begin{abstract}
Short films may be considered as a fast way to get into film industry or as an exercise with a particular genre that can prove director's talent. Besides these considerations, we can easily find early aesthetic and narrative concerns which are developed in short films and improved in long features films. It's the first step in what we can call "style".

The goal of this paper is to analyze the narrative and aesthetic strategies used by a successful director with a 'strong visual style', Paula Ortiz (Zaragoza, 1979), in her short films: El rostro de Ido (2003), Fotos de familia (2005) y El bueco de Tristán Boj (2008). Subsequently, these strategies will be compared with those used in two feature films: De tu ventana a la mía (2011) y La Novia (2015). For the analysis, we will work with the original scripts and theatrical releases.

Finally, to achieve our goal, we will use Vanoye and Goliot-Létés method (Précis d'analyse filmique, 1992) and Tarin and Marzal's film analysis proposal (Una propuesta metodológica para el análisis del texto filmico, 2005).
\end{abstract}

\section{Forma de citar este artículo en las bibliografías}

Ignacio Lasierra Pinto y Joseba Bonaut Iriarte (2016): "Estrategias narrativas y estéticas en el paso del cortometraje al largometraje: análisis del caso de Paula Ortiz”, en Miguel Hernández Communication Journal, nº7, páginas 419 a 441. Universidad Miguel Hernández, UMH (Elche-Alicante). Recuperado el _ de de 20__ de: @ink del artículo en mhjournal.org] 


\section{Introducción}

La importancia del cortometraje es, desde los orígenes del cine, indudable. Fue la primera forma cinematográfica que articuló y desarrolló un relato audiovisual y, además, el primer formato estándar industrial de las primeras grandes productoras cinematográficas.

Con el tiempo perdió su posición hegemónica en favor del largometraje, capaz de articular relatos más complejos y producto más atractivo para un público que ya buscaba referentes en los actores, directores, guionistas, etc.

Sin embargo, el cortometraje continuó como una fórmula diseñada para la experimentación artística, como lo ha sido habitualmente en las distintas vanguardias cinematográficas y movimientos "underground", así como una buena vía para los primeros pasos de los futuros cineastas. Al menos más accesible y una buena ventana de promoción para los productores ávidos de talentos creativos.

Esta naturaleza heterogénea del cortometraje ha provocado que todavía hoy existan diversas visiones sobre su función en la industria. En definitiva, la función del cortometraje se ha ido adaptando a las necesidades históricas e industriales, y ha variado según las características de cada región.

Por esta razón, los académicos no han encontrado un buen camino de análisis de este fenómeno y han tendido a obviarlo o bien a tratarlo desde una perspectiva bastante limitada y muy transversal. Apenas podemos encontrar verdaderos análisis fílmicos y estéticos sobre el cortometraje, o buenas referencias sobre la construcción narrativa del mismo (al contrario que sí ocurre en la literatura con la novela corta).

Casi todos los estudios se han centrado en breves panorámicas históricas del cortometraje en regiones o países, análisis de corrientes cinematográficas o casos singulares de éxito y/o experimentación formal, o bien aspectos de su limitada comercialización, centrándose en la vías de producción, realización y distribución de estas piezas cortas.

También es llamativo que el cortometraje aparece como un breve referente en las obras de los cineastas y que nunca se estudia de manera profunda como medio de adquisición de competencia, visión y estilo. Este aspecto contrasta claramente con la definición de cortometraje como vía de promoción del cineasta para afrontar retos mayores, largometrajes, o como ensayo de los mismos.

Por esta razón, el presente texto pretende tratar la importancia del cortometraje en los primeros pasos del cineasta (fundamentalmente, desde el punto de vista del director), y cómo estas piezas pueden ayudar a cimentar un estilo propio o universo en su carrera cinematográfica. En el fondo, se pretende abordar una cuestión más ambiciosa y de difícil solución en tan limitado espacio: ¿existen trasvases estéticos y narrativos entre los cortometrajes y largometrajes de un director? ¿Existe un enriquecimiento del estilo entre los cortometrajes y largometrajes?

Con la intención de avivar el debate, y animar a futuras investigaciones en este campo, el presente texto abordará el tema, en primer lugar, definiendo el concepto de cortometraje, su compleja naturaleza, y repasando algunos estudios realizados desde el ámbito académico. 
En segundo lugar, se profundizará en las posibilidades de trasvases narrativos estéticos y narrativos entre cortometrajes y largometrajes. Para conseguirlo, estableceremos una metodología de análisis fílmico adecuada y profundizaremos en un caso concreto: las estrategias narrativas y estéticas utilizadas por una directora de éxito y con un marcado sello personal dentro del cine español, Paula Ortiz (Zaragoza, 1979).

Veremos los resultados del análisis narrativo y estético de sus cortometrajes El rostro de Ido (2003), Fotos de familia (2005) y El bueco de Tristán Boj (2008), así como de sus dos largometrajes de ficción: De tu ventana a la mía (2011) y La Novia (2015).

Por último, plantearemos unas conclusiones que permitan contestar a la pregunta de investigación y animar a nuevos estudios en este campo.

\subsection{La naturaleza del cortometraje como obra cinematográfica.}

Para poder situar correctamente el objeto de estudio es necesario, en primera instancia, definir qué es cortometraje. Si tomamos la referencia de la American Motion Picture Academy, se entiende el cortometraje como "an original motion picture that has a running time of 40 minutes or less, including all credits" (AMPA, 2016). Como vemos, tan solo se hace referencia al concepto película (obra cinematográfica) y se establece una duración máxima que lo distingue del largometraje.

Si tomamos las definiciones que nos proporciona la Ley del Cine en España, se entiende cortometraje como "la película cinematográfica que tenga una duración inferior a sesenta minutos” (Ley 55/2007, de 28 de diciembre). De nuevo, se habla de película (obra) cinematográfica y, en este caso, pone el límite máximo de duración en 60 minutos. En ese mismo texto legal, se contrapone el cortometraje al largometraje, que se define como "la película cinematográfica que tenga una duración de sesenta minutos o superior, así como la que, con una duración superior a 45 minutos, sea producida en soporte de formato $70 \mathrm{~mm}$., con un mínimo de 8 perforaciones por imagen”. Al margen de la última apreciación (bastante discutible), se puede apreciar que la diferencia entre estos dos productos se reduce exclusivamente a su duración. En ningún momento se hace referencia a naturalezas diferentes.

Sánchez-Noriega insiste en la idea de la duración, aunque introduce el matiz de pieza de ficción al definir al cortometraje como "película de ficción -se suele excluir el documental- con una duración inferior a treinta minutos, aunque las distintas legislaciones de los países establecen el metraje mínimo y máximo” (Sánchez-Noriega, 2002: 695). De manera conclusiva, la Real Academia Española de la Lengua define al cortometraje como "película de corta e imprecisa duración” (DRAE, 2014).

Al margen de la duración, ¿qué otros elementos caracterizan al cortometraje? Como ya se ha comentado antes, se entiende al cortometraje como una obra cinematográfica, es decir, "una obra audiovisual, fijada en cualquier medio o soporte cuya elaboración quede definida la labor de creación, producción, montaje y posproducción” (Ley 55/2007).

Al cortometraje, a diferencia del largometraje, se le atribuye un carácter más libre, alejado de ciertas ataduras comerciales y, por tanto, más abierto a la experimentación. También, al carecer de un engranaje industrial que lo 
ampare y no disponer de parámetros estrictos o preestablecidos, el cortometraje se define por las diferentes formas, historias y géneros en los que se plasma.

Vanoye y Goliot-Lété confirman esta idea al afirma que "conviene tomar en cuenta las características específicas de estas formas cortas, diferenciándolas claramente de los largometrajes de ficción. Son características debidas a su duración, ciertamente, pero también a las condiciones de producción de estas películas". Y añaden: "Los cortometrajes pueden entrar en el marco de un contexto de creación pura o de encargo [...], son primeras obras, en ocasiones esbozos de obras más largas, pero también pueden formar parte de la carrera de un cineasta experimentado; o por fin de un conjunto estructurado como la película de sketches" (Vanoye y Goliot-Lété, 2008: 123-124).

Como explica Juan David Correa: "Además del tiempo, chay algo que defina al cortometraje? Sentido estricto, no, pero la percepción del mundo y las definiciones que lo abarcan cambian con la historia. Cuando el cine se inició todo era cortometraje, pero el concepto no se había inventado" (Correa, 2007: 5). Y continúa: "Mientras que los cronómetros imponen de manera despiadada las definiciones, los artistas se resisten a la clasificación. Una pregunta por los formatos y los contenidos lleva al taxonomista de las imágenes a salirse del cuadro [...] Los cortometrajes, con su modesta presencia y sus humildes presupuestos, pueden abarcar mucho más de lo que la pesada artillería del largometraje se atreve a explorar (Correa, 2007:5).

Ese "abarcar mucho más" apunta a otro rasgo definitorio del cortometraje: la necesidad de condensar y precisar el lenguaje y las historias. Su corta duración le condiciona. Es por esta razón que muchos autores han relacionado al cortometraje con con la novela corta o el cuento. Como explica Carro, "tanto el cortometraje de ficción como el cuento necesitan de una concentración y un rigor extremos, no permiten la menor distracción ni el mínimo exceso. Una imagen o una palabra de más o de menos puede hacerlos tambalear y, en consecuencia, derrumbar toda la estructura" (Carro, 1997).

Como se puede ver, el cortometraje se define como una obra cinematográfica sin estructuras y convenciones rígidas, abierta a la experimentación y al juego, que se adapta a las necesidades históricas y temáticas, y que es directa y concisa. Sin embargo, el cortometraje no se reduce a puro "cuento". El cortometraje se define en las diferentes formas en las que puede plasmarse. Así lo explica un libro ya clásico, Sprache des Kurajfilms de Hilmar Hoffmann (1981), con excelentes explicaciones sobre el lenguaje del cortometraje.

Hoffmann diferencia, en primera instancia, dos tipos de cortometrajes. Encontramos aquellos en los que se reconoce la propuesta narrativa y estructura dramática del largometraje (que define como "Película de ficción breve" o Kuržer Spielfilm), y otros en los que se pueden detectar características, lenguaje autónomo y convenciones alejadas del largometraje (definidas como "cortometraje de ficción” o Kurz-Spielfilm) (Hoffmann, 1981).

Estos dos grandes bloques de cortometrajes, especialmente el último, llevan a estas piezas cortas a poder plasmarse en diversos tipos de cortometrajes: de ficción, documental, animación, experimental, videoarte, etc. Y, a su vez, y por su propia autonomía, generan convenciones narrativas en forma de géneros propios. De este modo, los géneros de los cortometrajes han sido clasificados de muchas maneras. Hoffmann habla de ensayo, el cuento corto, la anécdota, la parábola, el panfleto, el aforismo, el editorial, el folletín, la farsa, el sketch, poesía, etc. (Hoffmann, 1981). Otros 
autores, como Saara Canttell, propone cinco categorías básicas: el cortometraje como poema, el cortometraje metafórico, como chiste (o anécdota), el comercial y el "zen" de la realización del cortometraje (espacio del cortometraje como lugar espiritual y de meditación) (Cantell, 2004).

Sea la clasificación que sea, parece obvio que el cortometraje se define de manera autónoma y desarrolla sus propios rasgos distintivos como obra cinematográfica. Los más destacados suelen centrarse en la citada economía de medios del cortometraje que lo lleva, de forma natural, a una densificación y abstracción mayor o, de forma opuesta, a una reducción anecdótica de la realidad (Meier, 2013). Por otro lado, el cortometraje suele potenciar el lenguaje visual, una especie de "reencuentro" con el famoso "cine de atracciones" del período mudo, "juega" con las fronteras entre ficción y realidad y plantea nuevas convenciones narrativas que permiten la hibridación y la experimentación sonora, narrativa y estética (Meier, 2013).

Al definir la esencia del cortometraje, se puede ver rápidamente que se une a conceptos como "juego" o “experimentación”. Aquí radica una de las funciones básicas del cortometraje: permitir probarse al cineasta, jugar con el lenguaje y la narración y encontrar su punto de vista.

Sin embargo, otra función del cortometraje se ha ido revelando progresivamente en la industria cinematográfica. La condición no comercial del cortometraje, que lo diferencia del largometraje, hace que este tipo de obras se estructure de forma precaria en relación a Festivales de Cine y su distribución se limite a certámenes y muestras dedicadas al cortometraje. La mejora en las condiciones de producción del cortometraje y el desarrollo de estos certámenes ha provocado, tal y como explican Zubiaur, Lazcano y de Arroyabe, que "el cortometraje pase así a convertirse en una carta de presentación de las potencialidades de los jóvenes realizadores ante una industria sedienta de relevo generacional" (Zubiaur, Lazcano y de Arroyabe, 2011: 4).

Esta mutación del cortometraje, de ejercicio en busca de estilo a prueba de talento comercial, ha dificultado el análisis del cortometraje como obra cinematográfica. De esta forma, el cortometraje (y quien lo hace) se debate entre esta doble función actual y ha provocado que los rasgos distintivos comentados anteriormente sean cada vez más confusos o se asemejen más al largometraje.

Como explican Velázquez y Ramírez (hablando de la situación del cortometraje en España durante los años noventa): "El cortometraje como espacio de búsqueda de una mirada más personal, o de investigación sobre el propio lenguaje y sus límites en la representación de lo exterior, ha sufrido una sustancial mutación [...]. La búsqueda de unas formas expresivas propias, o simplemente la investigación en el territorio del lenguaje, que en muchas ocasiones entrañaba la producción de obras parcialmente fallidas o de muy escaso interés general, ha sido un territorio cada vez más abandonado en función de otra búsqueda, más centrada en las mímesis genéricas o en los mecanismos de interacción con el espectador" (Velázquez y Ramírez, 2000: 344).

Como se ha podido ver en este apartado, el cortometraje es una obra cinematográfica con identidad propia pero con gran heterogeneidad en sus funciones, objetivos, y en la actualidad, en sus rasgos distintivos de lenguaje. El director de un cortometraje se encuentra con una oportunidad de contar una historia corta, jugar con el lenguaje, desarrollar un mundo imaginario o real de animación o experimentar artísticamente. Pero, al mismo tiempo, el cortometraje se 
presenta al cineasta como un primer acceso al mundo del cine, un paso para configurar un punto de vista propio y demostrar sus capacidades comerciales para afrontar el reto del largometraje.

\subsection{El concepto de estilo}

Como se ha visto, el cortometraje se presenta al cineasta como un primer acceso al mundo del cine, un paso para configurar un punto de vista propio y demostrar sus capacidades comerciales para afrontar el reto del largometraje.

Pensamos que toda estrategia narrativa y estética, desde el inicio de la carrera artística de un cineasta, es una pequeña (gran) búsqueda de un estilo que afronte unos temas recurrentes, espacios comunes y, en el fondo, un universo propio. De ahí que es necesario definir el concepto de estilo para poder entender mejor a qué nos enfrentamos.

El cortometraje, como primera prueba o ejercicio de un cineasta, es una buena oportunidad para que el director pueda jugar con el lenguaje fílmico. Progresivamente, el cineasta irá dominando más las herramientas de las que dispone para elaborar un discurso propio. Ahí, el artista tendrá que utilizar el lenguaje fílmico de la mejor manera posible, conforme a sus posibilidades para lograr el fin artístico de la obra de la forma más efectiva. En el fondo, la elección y uso de los elementos del lenguaje fílmico será consecuencia de las limitaciones históricas y de una elección deliberada. Ahí surge el estilo (Cousins, 2012).

Bordwell y Thompson definen a estilo como "aquel sistema formal de la película que organiza las técnicas cinematográficas. [...] También podemos aplicar el término estilo para describir el uso característico de técnicas que hace un único cineasta o un grupo de ellos (Bordwell y Thompson, 1993: 335).

Podremos hablar de estilo cuando surge esa elección, cuando el uso de las herramientas narrativas y estéticas se ponen al servicio de la obra de la manera más efectiva. En definitiva, es el abandono por parte del artista de la tiranía de la técnica y la sublimación de esta a la estética (Martin, 2002: 265). O como lo expresaría Robert Bresson: estilo es "todo lo que no es técnica" (Bresson, 1975: 60)

No se puede olvidar el papel clave del espectador en la configuración de un estilo propio. Como explican Bordwell y Thompson: "el espectador también mantiene una relación con el estilo. Aunque muy pocas veces somos conscientes de este hecho, tendemos a mantener expectativas en torno al estilo. [... Al igual que otro tipo de expectativas, las estilísticas derivan de nuestra experiencia del mundo en general y de nuestra experiencia del cine y otros medios. El estilo de una película concreta puede confirmar nuestras expectativas, modificarlas, defraudarlas o desafiarlas. [...] El espectador tal vez no advierta conscientemente el estilo cinematográfico, pero, desde luego, realiza una importante contribución al efecto y el significado global de la película". (Bordwell y Thompson, 1993: 334-335)

Este aspecto es esencial, porque el espectador y su identificación con la obra y el cineasta consolida, reafirma y hace consciente al propio director de su "estilo". Podemos afirmar que esta relación es casi una necesidad. Así lo afirmaba, de manera melancólica y poética, el director polaco Krsyzstof Kiesloswki: "Para mí la película que quiero hacer es la película que puedo hacer. No tengo otras, no pienso en otras. No necesito tener millones de espectadores, pero quiero tener la sensación de que alguien me necesita para algo. Incluso cuando hago películas -como todos mis compañeros- 
para mí mismo, busco a alguien que, como una quinceañera de Francia, me diga: he visto la 'La doble vida de Verónica' y he sentido que existe algo como el alma. Si no tengo en cuenta lo que dice esa chica, no tiene sentido sacar la cámara del cajón...” (Bardzinska, 2015).

Con todo lo explicado, no podemos obviar la importancia de la obra de un cineasta, incluidos los cortometrajes, para poder identificar y definir los rasgos de su estilo, que solo se muestran con "un análisis global de la forma única en que las técnicas se relacionan entre sí en la obra de un cineasta" (Bordwell y Thompson, 1993: 335).

\section{Metodología}

Tal y como se ha explicado en el primer epígrafe, este texto pretende contribuir a enriquecer los estudios sobre el cortometraje y su influencia estética. Por ello, proponemos el análisis fílmico de la obra de una cineasta de éxito reciente, Paula Ortiz, desde la perspectiva narrativa y estética, en la búsqueda de encontrar ciertas claves sobre el papel del cortometraje en el desarrollo de un estilo y los potenciales trasvases entre el cortometraje y el largometraje. Para lograrlo, pasamos a explicar nuestra propuesta metodológica y la idoneidad del caso analizado.

\subsection{Propuesta metodológica.}

Para poder conseguir los objetivos propuestos, procederemos a utilizar la propuesta metodológica de análisis del texto filmico planteada por Gómez Tarín y Marzal (2005), basada en un libro clásico de Francis Vanoye y Goliot-Léte, Principios de análisis cinematográfico.

Son estos últimos autores quienes explican la idoneidad del análisis fílmico del cortometraje, del mismo modo que se realiza con el largometraje, y nos animan a utilizarlo para identificar rasgos de estilo: "las obras cinematográficas cortas exhiben, de manera más evidente que los largometrajes, sus dispositivos (narrativos o discursivos), su estructura dramática y rítmica, la forma-sentido que produce su impacto. [...] La forma global de la película corta se ofrece a la percepción y, por tanto, a un análisis más fácil. Se puede observar, por lo demás, que numerosos cortometrajes están elaborados a partir de formas múltiples o de configuraciones retóricas perfectamente identificables" (Vanoye y GoliotLété, 2008: 131-132).

Teniendo en cuenta esta afirmación, se planteará un análisis fílmico híbrido de cortometrajes y largometrajes, que partirá del siguiente precepto ya formulado por Aumont y Marie (1988: 8): “Consideraremos el film como una obra artística autónoma, susceptible de engendrar un texto (análisis textual) que ancla sus significaciones sobre estructuras narrativas (análisis narratológico), sobre aspectos visuales y sonoros (análisis icónico), y produce un efecto particular sobre el espectador (análisis psicoanalítico). Esta obra debe ser igualmente observada en el seno de la historia de las formas, los estilos y su evolución".

Además, basándonos en la anterior afirmación, el método se basará en la siguiente concepción del análisis fílmico planteada por Gómez Tarín y Marzal (2005: 2):

1. Elementos objetivables:

a) Un texto y su estructura (análisis textual) 
b) Un entorno de producción y recepción (análisis contextual)

c) Una formulación icónica de los recursos expresivos (análisis icónico)

2. Elementos no objetivables:

a) Recursos narrativos (análisis narratológico)

b) Enunciación y punto de vista

3. Interpretación (elementos subjetivos)
a) Interpretación global
b) Juicio crítico

Para poder conseguir realizar un análisis del texto fílmico que permita identificar el estilo desde las tres dimensiones comentadas anteriormente, se ha procedido a realizar un trabajo que sigue la siguiente fórmula (Gómez Tarín y Marzal, 2005: 15-17):

-Fase previa: recogida de información documental sobre la producción, contexto y recepción. Desglose visual plano a plano (cortometrajes y largometrajes) y definición de principios ordenadores de la representación.

-Fase descriptiva: generación de instrumentos de análisis (imágenes, escenas, fotogramas), plasmación del análisis (desde la descripción básica hasta los parámetros contextuales y textuales) por secuencias.

-Fase descriptivo-interpretativa: plasmación escrita del análisis, enumerando los recursos expresivos (planos, ángulos de cámara, profundidad de campo, etc.), las relaciones entre sonido e imagen, recursos narrativos (relato, personajes, trama, relaciones personaje-narrador, punto de vista y de escucha, enunciación fílmica). Esta fase es la que acabará plasmada en los resultados de manera sucinta en el siguiente epígrafe.

\subsection{El caso de Paula Ortiz: de El rostro de Ido (2003) a La Novia (2015).}

Una vez se ha explicado la metodología de análisis, pasamos a comentar la idoneidad del caso escogido para el estudio. Se ha decidido analizar la obra cinematográfica de Paula Ortiz, joven directora aragonesa, por las siguientes razones:

-Éxito reciente: su última película, La Novia (2015), recibió 12 nominaciones en la última edición de los premios de la academia española ("los Goya") y ganó dos (mejor actriz de reparto y mejor fotografía), obtuvo seis premios Feroz de la Asociación de Informadores Cinematográficos de España y fue preseleccionada por España como finalista para optar a la carrera de los Oscar junto con El Olivo (Iciar Bollaín, 2016) y Julieta (Pedro Almodóvar, 2016).

-Formación integral en el mundo del cine y con experiencia y carrera internacional (La novia fue una coproducción entre tres países -España, Alemania y Turquía- y su próxima película, Barba azul, se rodará en inglés).

-Generación joven que impulsó el cortometraje en España y, en concreto, en su región: Aragón. 
-Fuerte implicación con el papel de la mujer en el mundo cinematográfico: es miembro de la junta directiva de CIMA (Asamblea de Mujeres Cineastas de España) y vicepresidenta de EWA Network (European Women Audiovisual Network).

-Proviene de un territorio con poco desarrollo industrial cinematográfico y sus cortometrajes no fueron un éxito en los festivales (existe una necesidad de una mayor reivindicación del estilo).

Para intentar obtener algunas respuestas a la pregunta de la investigación, se ha aplicado la metodología anteriormente comentada a toda la obra cinematográfica de Paula Ortiz (tres cortometrajes y dos largometrajes):

-El rostro de Ido (cortometraje, 15 minutos, 2003): este cortometraje nos presenta cómo en medio de ninguna parte, un hombre enmascarado cuenta su historia. Hace mucho tiempo, él fue el rostro más bello de la ciudad. Su rostro era tan bello que un día decidió guardarlo en una caja a salvo del tiempo.

-Fotos de familia (cortometraje, 15 minutos, 2005): este cortometraje nos explica cómo un anciano, cada mañana, retrata con su cámara las calles con otra mirada y camina con otros pasos y lentitud. Su vejez, su barba canosa, su alegría cansada siguen soñando un día y otro, aprendiendo a mirar de nuevo.

-El bueco de Tristán Boj (cortometraje, 19 minutos, 2008): este cortometraje nos muestra a un niño que ve en un escaparate una avioneta rara que vuela a lo más alto del Himalaya. Un títere desea marcharse con una bailarina juntos, muy lejos. Solo el titiritero sabe que, a veces, hay que aprender a vivir sin aquello que más amas.

-De tu ventana a la mía (largometraje, 96 minutos, 2011): este largometraje nos habla de tres mujeres, de edades y épocas distintas, que han fracasado en el amor, tienen que afrontar la vida en un ambiente cerrado y hostil. Son mujeres que no pudieron elegir su camino y tuvieron que vivir una vida soñada, imaginada, recordada, cosiendo junto a su ventana.

-La novia (largometraje, 93 minutos, 2015): este largometraje es una adaptación de Bodas de sangre de Federico García Lorca. Desde pequeños, Leonardo, el novio, y la novia han formado un triángulo inseparable, pero cuando se acerca la fecha de la boda, las cosas se complican ya que entre ella y Leonardo siempre ha habido algo más que amistad. La creciente tensión entre ambos es como un hilo invisible que no se puede explicar, pero tampoco romper.

El trabajo previo realizado se ha fundamentado en el visionado de todas las obras comentadas, la descripción del entorno de producción de las piezas cinematográficas (especialmente todo lo que tiene que ver con los cortometrajes, por su claro carácter regional) y la elaboración de un esquema de análisis basado en los siguientes aspectos:

-Identificación y repetición de estructuras narrativas

-Punto de vista y focalización narrativas

-Uso recurrente de elementos iconográficos 
-Fundamentos de puesta en escena y del lenguaje cinematográfico

Con todo ello, se ha decidido centrar la interpretación del análisis en siete puntos fundamentales que recogen (y se detallan en el siguiente epígrafe), a nuestro parecer, una continuidad en el estilo en el paso del cortometraje al largometraje:

A- Uso recurrente de los mismos actores a lo largo de la filmografía.

B- Presencia de prólogos y epílogos como elementos estructurales del relato.

C- Abundancia de recursos expresivos literarios a través de los diálogos.

D- "Cosificación" de los conflictos y representación del estado anímico de los personajes a través de los objetos

E- Insistencia en la utilización de la cámara lenta y las secuencias de montaje con un fin expresivo y potenciación de los elementos sonoros para transmitir emociones.

F- Introducción del espacio oníricos para explorar las emociones de los personajes.

G- Búsqueda de lugares comunes: utilización del espejo y del entorno natural.

\section{Resultados}

\subsection{Uso recurrente de los mismos actores a lo largo de toda la filmografía.}

Siguiendo la metodología expuesta por Gómez Tarín y Marzal, la primera característica objetiva en la trayectoria fílmica de Paula Ortiz es la continuidad actoral con la que la directora ha trabajado tanto en sus cortometrajes, como en sus largometrajes. Esta característica de contexto, permite observar que Paula Ortiz ha confiado en un pequeño grupo de actores en sus cortometrajes, con los que posteriormente ha trabajado en sus largometrajes. Esta variable objetiva que pertenece al entorno contextual y de producción permite, no obstante, una búsqueda de un estilo determinado en la dirección actoral, cualidad artística de relevancia en cualquier obra cinematográfica.

Los actores con los que Paula Ortiz ha trabajado en más ocasiones son Carlos Álvarez-Nóvoa y Luisa Gavasa, con quien la directora ha rodado cuatro de las cinco producciones que ha realizado hasta la fecha. El actor Carlos ÁlvarezNóvoa aparece en cuatro de las producciones cinematográficas dirigidas por Ortiz. La directora le dedica la película La novia, con un rótulo final que reza "Dedicada a Carlos Álvarez-Nóvoa, compañero, amigo, maestro", debido al fallecimiento del veterano actor antes del estreno de la misma. Álvarez Novoa interpreta en El rostro de Ido a un anciano que escucha el relato del protagonista, en un papel no protagonista. En Fotos de familia, interpreta el papel protagonista de la historia, dando vida a un anciano que recorre las calles de Zaragoza sacando fotos para cubrir su soledad. En De tu ventana a la mía interpreta al padre de Violeta (Leticia Dolera), una de las tres protagonistas de la película. Y finalmente, en La novia, ejerce como padre de "La novia" (Inma Cuesta). La vinculación de la directora con el actor es clara y el trabajo desarrollado con el actor también, lo cual implica una confianza depositada en él extendida durante más de una década y trasladada del cortometraje al largometraje. Sucede lo mismo con Luisa Gavasa. La actriz aragonesa, gracias a su interpretación en La novia, dando vida a la madre de "El novio", consiguió el Premio Goya a mejor actriz de reparto. Sin embargo, el trabajo desarrollado entre Luisa Gavasa y Paula Ortiz se extiende desde los inicios de la carrera de la directora. En Fotos de familia interpreta a la mujer con la que el anciano protagonista se ve en sus sueños y en El bueco de Tristán Boj pone voz a uno de los títeres de la historia (la profesora de ballet). En su primer largometraje, Paula confió en Luisa Gavasa para que esta interpretara a una de las tres historias protagonizadas por 
una mujer. La de Luisa (comparten nombre la actriz y el personaje interpretado), una mujer que vive con su hermana y a la que se diagnostica cáncer. En menor medida, Ortiz también ha trabajado en sus producciones con otros actores de forma recurrente, como en el caso de Álex Ángulo (protagonista de El bueco de Tristán Boj y personaje de reparto en De tu ventana a la mía) o Leticia Dolera (protagonista de De tu ventana a la mía y personaje de reparto en La novia). Por tanto, la búsqueda de una forma determinada de dirección actoral, así como la confianza establecida entre la directora y sus actores "fetiche", cobran sentido si observamos que en buena medida, estos ya estaban presentes en sus cortometrajes.

\subsection{Presencia de prólogos y epílogos como elementos estructurales del relato.}

En cuanto al uso de elementos narratológicos, en buena parte de la filmografía de Paula Ortiz, se puede apreciar cómo la guionista utiliza el prólogo y el epílogo como elementos que inician y clausuran sus relatos. Paula Ortiz, quien estudió filología hispánica y posee una formación literaria amplia, imita un modelo literario muy presente a lo largo de su filmografía, algo menos habitual en el medio cinematográfico. Ortiz comienza tanto De tu ventana a la mía como La novia, con imágenes descontextualizadas del propio relato en sí que invitan a acceder a la historia que se presenta a continuación. En De tu ventana a la mía, la película comienza con una voz en off extradiegética que se solapa con imágenes de los tres personajes protagonistas en sus respectivos entornos. Se nos presenta a los personajes en sus espacios. Los tres se cortan en el dedo y los tres sangran. A los tres les une un hilo rojo que parece unificar las tres historias y los tres quedan conectados desde un primer momento por esa voz en off, que en su primer parlamento dice: "Hay historias de amor que son como amapolas. Rojas, frágiles, casi viento. Y aún así, se agarran a la garganta”. En este caso, el guion se aprovecha de la primera frase de la película para establecer las coordinadas temáticas que Ortiz aborda a lo largo de la película y también se usa como antesala, prólogo, antes de abordar directamente cada una de las tres historia. Utilizando este recurso, de marcado carácter literario, en La novia sucede exactamente lo mismo. Desmarcándose de la estructura que García Lorca utilizó en Bodas de Sangre, antes del rótulo inicial y del título de la película, La novia contiene una secuencia introductoria en la que vemos a la protagonista, desde un plano cenital, fundida en medio de un lodazal de barro. Viste con unas telas manchadas de sangre. Y no le vemos el rostro. Despierta de una exhalación como un resorte e intenta incorporarse, quitándose las telas y llevándose la mano al vientre dolorida. Una anticipación narrativa de lo que está por venir y del final de la propia historia, que se retoma en el desenlace de la película con el mismo personaje caminando errante hacia ninguna parte, a la vez que se descubre que también es la anciana que se le aparece a la novia durante toda la película. Desmarcándose así de la estructura narrativa utilizada por Federico García Lorca en Bodas de Sangre, los coguionistas Paula Ortiz y Javier García Arreondo, en su adaptación de la obra de Lorca, se decantan por el uso del prólogo y del epílogo para abrir y clausurar el guion de La novia.

Este recurso, usado en ambos largometrajes de la directora, ya estaba presente en El rostro de Ido, el primer cortometraje de Ortiz. La narración de su primer cortometraje comienza y termina, no solo con el mismo plano general, sino con una acción muy similar. Dos personajes caminan en medio de un desierto hacia una mesa que les espera junto a dos sillas. Y una vez se ha contado el relato, ambos personajes dejan ese espacio y vuelve a marcharse por el desierto. Misma estructura y mismo plano para abrir y clausurar el relato. En El hueco de Tristán Boj, antes del rótulo inicial, los créditos se solapan con el títere de la bailarina danzando sobre un fondo negro. Baila en ninguna parte. Nuevamente, se nos presenta a un personaje antes de que empiece la propia narración, tal y como sucede en $D e$ tu ventana a la mía o en La novia. Es un recurso narratológico que marca el estilo narrativo de la directora y que más allá 
de sus dos largometrajes, ya estaba presente en sus cortometrajes, abriendo y clausurando el relato al estilo literario, como si sus películas quisieran emparentarse así con la estructura de los cuentos y las fábulas populares.

\subsection{Abundancia de recursos expresivos literarios a través de los diálogos de los personajes.}

El estilo buscado en los diálogos en las películas de Ortiz no renuncia a la importación de recursos literarios. En la adaptación de Bodas de Sangre de Federico García Lorca, se respetan los parlamentos originales del poeta andaluz, por lo que La novia no es representativa en este caso, dado que los diálogos están basados en una obra teatral original escrita en verso. Sin embargo, en sus guiones originales (cuatro de las cinco producciones de la directora), Ortiz utiliza de forma habitual la retórica literaria para que sus personajes hablen, de forma que traslada un lenguaje más literario al medio cinematográfico. Sirvan como ejemplo algunos de los diálogos extraídos de sus cortometrajes, como el que se dice en El rostro de Ido: "Hace poco pasé por delante de la tienda. Fue como si el corazón se hubiese parado", en un claro símil literario o el emitido en Fotos de familia: "La casa se queda con un olor a pensamientos" en una clara metáfora. En El bueco de Tristán Boj se sigue haciendo uso de recursos expresivos literarios en diálogos como "Cuando tienes que dejar atrás algo que amas, es como si tu corazón no quisiera ir contigo" o "Los huecos duelen cuando no hay nada que los cubra" y en De tu ventana a la mía son varias las referencias alegóricas, muy visuales, que se realizan, partiendo de la primera frase de la película que supone toda una declaración de intenciones: "Hay historias de amor que son como amapolas. Rojas, frágiles, casi viento". Por tanto, los diálogos en la filmografía de Paula Ortiz, más allá de una mera utilización como elementos narrativos para hacer avanzar la trama, para informar o para construir a los personajes, también son usados como elementos alegóricos, sustancialmente poéticos, que pretenden evocar, simbolizar o recrear espacios visuales y sensitivos, desprendiéndose de un uso meramente narratológico. Un recurso mucho más propio de otros medios como el medio literario, no tan habitual en el medio cinematográfico que construye un estilo propio en cuanto a la escritura de diálogos se refiere. Este trasvase literario al medio cinematográfico se ve culminado en la última película rodada hasta la fecha donde, como se ha indicado, se acude directamente a los versos de García Lorca como diálogos de la películaํㅗ․

\section{4 "Cosificación" de los conflictos y representación del estado anímico de los personajes a través de los objetos.}

En cuanto a la utilización de ciertos elementos iconográficos, desde su primer cortometraje, Paula Ortiz ha utilizado numerosos objetos como elementos imprescindibles dentro de sus historias. O bien los ha usado para "cosificar" el conflicto dramático, o bien los ha utilizado como representaciones de los estados anímicos de los personajes. La guionista y directora aragonesa otorga mucha importancia a ciertos elementos del atrezæo de la puesta en escena, que más allá de un uso descriptivo, sirven como catalizadores de sus relatos.

En su primer cortometraje, El rostro de Ido, aparece una caja donde el protagonista guarda su rosto. Esta se utiliza como objeto con el que visualizar el conflicto del protagonista, una especie de Dorian Grey, con un rostro perfecto, que tiene miedo a envejecer. En su segundo trabajo, Fotos de familia, las fotografías del anciano representan sus deseos, sus

\footnotetext{
${ }^{1}$ Al igual que en su momento hiciera Pilar Miró respetando el texto íntegro de Lope de Vega en El perro del hortelano (Pilar Miró, 1996, España).
} 
sueños, sus ansias de llevar una vida con otras personas que no tiene. El fotógrafo las colecciona casi de forma obsesiva. Igualmente, en El bueco de Tristán Boj, el niño desea una avioneta que hay en el escaparate de la tienda de títeres. Sobre la avioneta, giran varios diálogos. Esta actúa como catalizador de la historia, pero también representa el conflicto del niño de querer volar lejos aprendiendo vivir sin ciertas cosas. Como dice una de las frases del guion: "vas a perder cosas mucho más importantes que esa avioneta. Pero no pasa nada. Vas a aprender a vivir sin ellas".

Fotograma 1. Caja en El rostro de Ido.

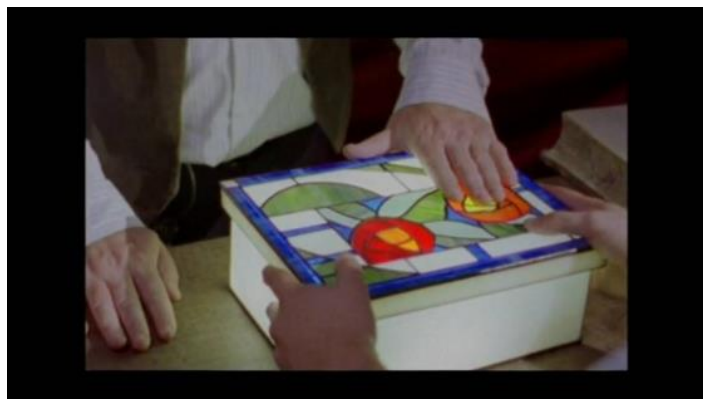

Fotograma 2. Avioneta en El bueco de Tristán Boj.

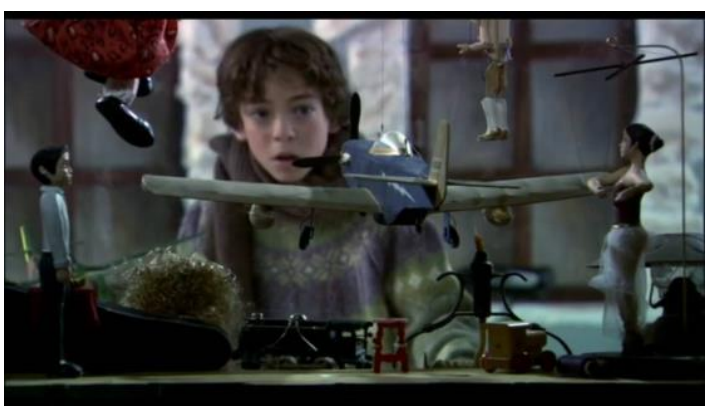

La integración de estos objetos como elementos en los que se "cosifican” los conflictos de los personaje y también como representación de sus diferentes estados anímicos, también está presente en los largometrajes de Ortiz. En De tu ventana a la mía, son varios los objetos a los que Ortiz les da una importancia especial: el ovillo rojo que une simbólicamente a las tres protagonistas y que va pasando de una historia a otra por las manos de las mujeres (llegando incluso a mancharse de sangre en una escena), las amapolas (que además dan nombre a la productora de la película "Amapola Films"), que sirven para establecer una comparación directa con el personaje de Violeta (Leticia Dolera), por su fragilidad y que también le sirven a Violeta para descubrir que su tío le miente, la fotografía de Alfredo Kraus que, al igual que sucediera en Fotos de familia, representa el deseo interno del personaje de Luisa de vivir un amor verdadero, o la cuerda con la que se promete el personaje de Inés (Maribel Verdú) con su marido y que al final, a modo de cumplimiento, se recupera para indicar que su marido ha muerto, cuando el Guardia Civil le devuelve la misma cuerda y los zapatos. En La Novia, igualmente, hay numerosos objetos que cobran especial relevancia y sobre los que la directora se detiene en varias ocasiones. El zootropo, rueda que bien pudiera representar las ansias de la novia de escapar, pero también el círculo continuo en el que está atrapada, el cuchillo de cristal, o los pendientes de la novia que representan la vida no elegida por la novia y a los que la directora dedica un plano una vez el novio descubre que esta ha escapado con Leonardo. En definitiva, son varios los objetos que más allá de un uso decorativo u ornamental, se usan como símbolos dentro de sus películas, siempre a través del uso del plano detalle que los diferencia, los enmarca y los singulariza del resto de elementos, configurando así una repetición estilística presente en toda la obra de la directora, tal y como se puede apreciar en los siguientes fotogramas.
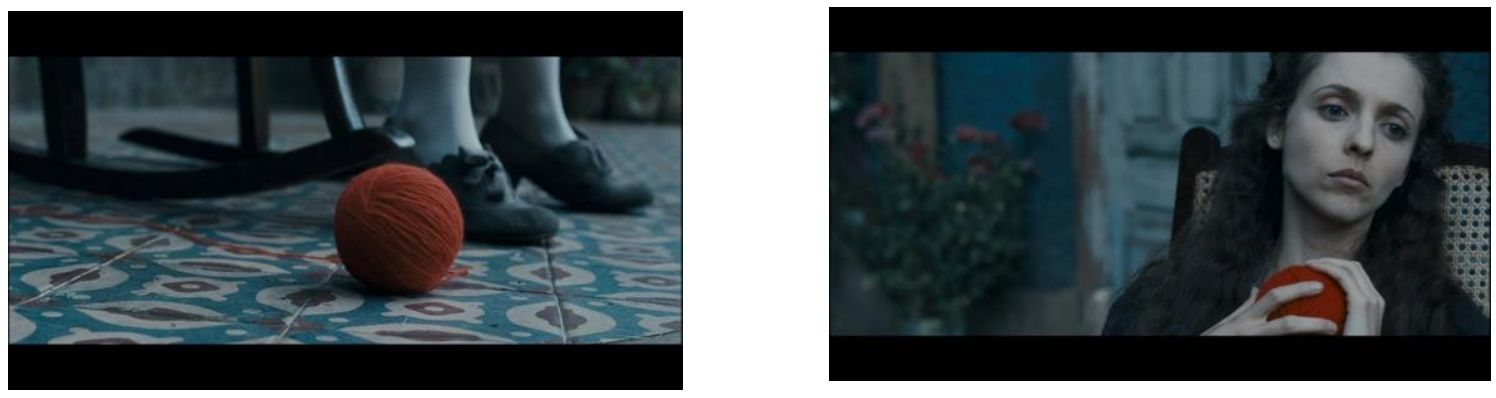

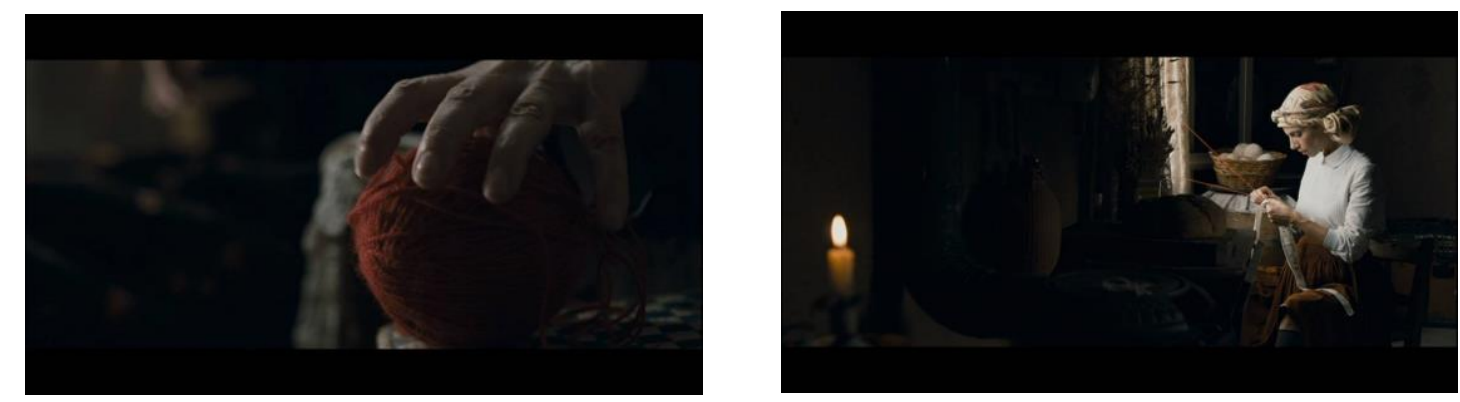

Fotogramas 3, 4, 5 y 6. Ovillo en De tu ventana a la mía.
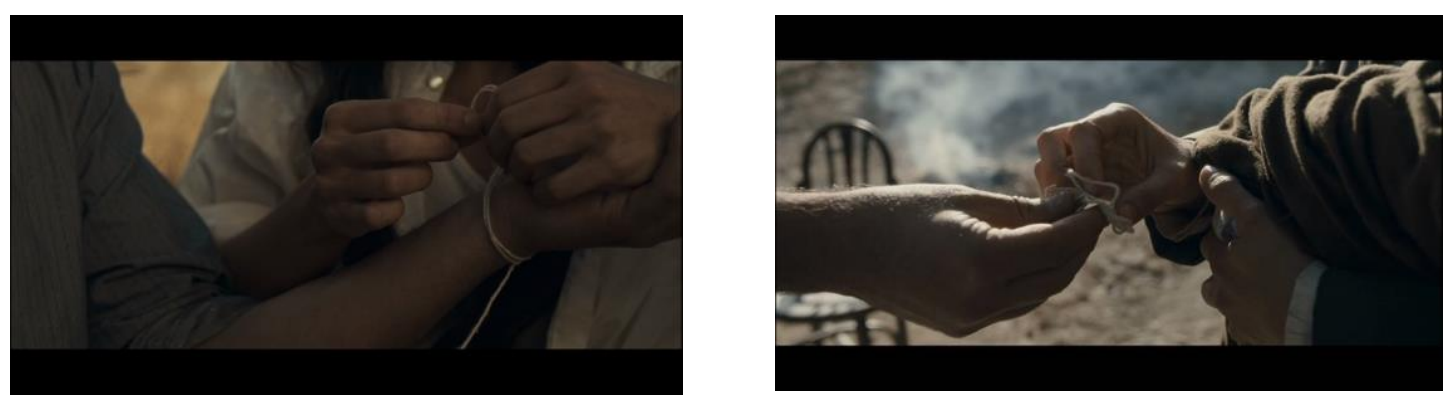

Fotogramas 7 y 8 . Cuerda de Inés en De tu ventana a la mía.
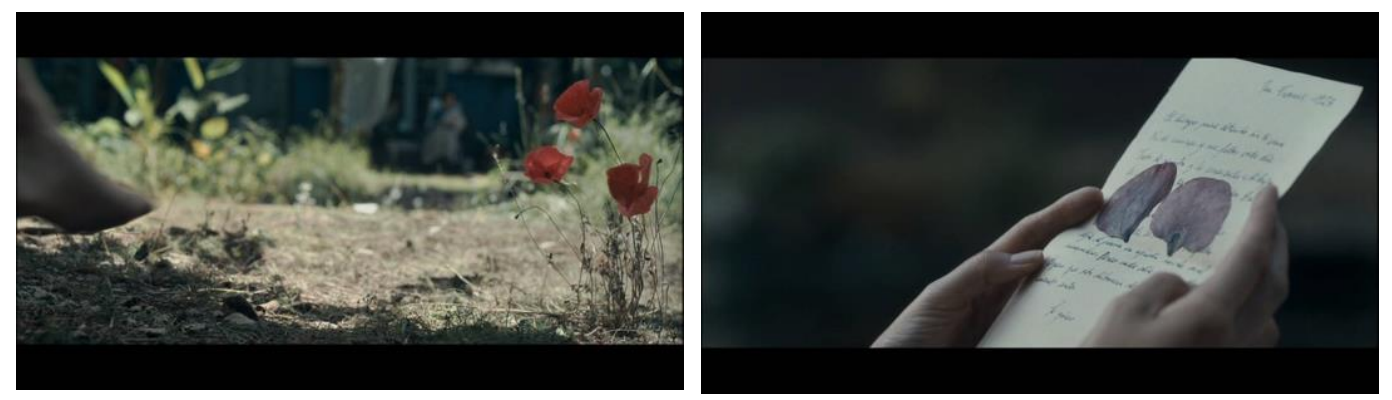

Fotogramas 9 y 10. Amapolas en De tu ventana a la mía.
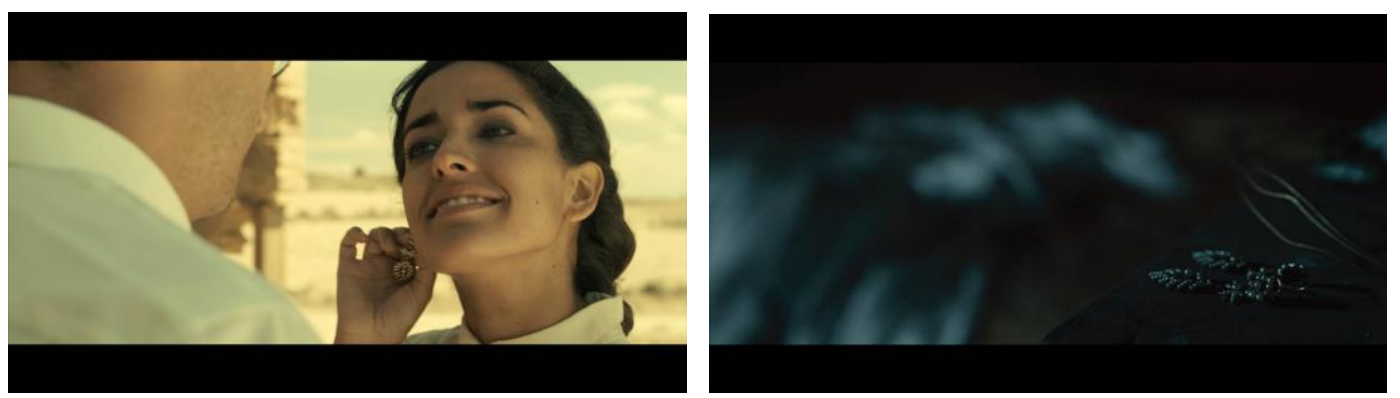

Fotogramas 11 y 12. Pendientes en La novia. 


\subsection{Insistencia en la utilización cámara lenta y de las secuencias elaboradas de montaje como recursos expresivos y potenciación de los elementos sonoros para transmitir emociones.}

Tanto en los cortometrajes, como en los largometrajes, Paula Ortiz utiliza de forma habitual la dilatación temporal a través de la cámara lenta en momentos de especial interés dramático, así como las secuencias elaboradas musicales en momentos claves como el clímax de sus historias.

Sucede así en su primer cortometraje, El rostro de Ido, donde la directora usa la cámara lenta y la música en el clímax y resolución de la historia. Una cámara lenta que, en este caso y ante la falta de medios de producción habitual en los primeros trabajos de un director, se contrarrestan con un efecto de ralentización de montaje que, subraya, no obstante, en momento final de la historia. Igualmente sucede en El bueco de Tristán Boj. Ortiz busca la emoción en el espectador a través de la yuxtaposición de imágenes, la cámara lenta y los acordes musicales, unidas en un montaje en paralelo entre los dos títeres, la bailarina y el títere que se marcha en tren. En Fotos de familia, a pesar de que el clímax de la historia no llega mediante el uso de la cámara lenta, esta sí se utiliza en varios momentos del cortometraje para subrayar los diferentes estados emocionales del protagonista de la historia.

Esta exploración de recursos se traslada de forma notable a sus dos largometrajes. En De tu ventana a la mía, hay numerosas secuencias que hacen uso de la cámara lenta, algunas de ellas de especial relevancia dramática. Como el inicio de la historia, donde la directora nos presenta a las tres protagonistas mediante planos detalles a cámara lenta y suaves travellings de acercamiento o alejamiento. O el final de la historia, donde vemos al personaje de Luisa (Luisa Gavasa), entre la multitud, pero con una dilatación temporal que llega, nuevamente, mediante la cámara lenta, mientras de fondo se escucha el tema cantado por Carmen Paris “Yo vengo a ofrecer mi corazón”. En La novia, igualmente, la directora vuelve a decantarse por este recurso expresivo, no solo en el clímax de la película (la lucha a cuchillo entre Leonardo y El novio), sino también en los momentos de mayor intensidad dramática de la película. El porcentaje de planos rodados a cámara lenta es muy amplio y algunas secuencias se sustentan, principalmente, bajo este recurso expresivo que además altera la percepción temporal del espectador. Sucede así en el baile de La novia tras la boda, en las ensoñaciones que tiene esta, o en la presentación de Leonardo a lomos de su caballo negro. Al utilizar la cámara lenta, los recursos expresivos sonoros también ganan en importancia y relevancia.

A su vez, Ortiz potencia claramente en sus películas el espacio sonoro, adueñándose este de la imagen y cobrando en algunos casos, más importancia que la propia significación del plano en sí. Ortiz, mediante sonidos cargados de eco que se mezclan con los diferentes temas musicales utilizados por la directora en sus secuencias a cámara lenta, combina ambas técnicas para transmitir los estados emocionales de sus personajes, sustentando los momentos más relevantes de sus películas, bajo diferentes lo que se podría denominar como "montajes de sensaciones" (recurso que se asocia habitualmente, por ejemplo, al estilo de otros directores como Terrence Malick, Zhang Yimou o Wong Kar Wai), donde lo relevante es lo que se ve y lo que se escucha y no tanto lo que se pueda decir. Un recurso que se considera más estético que narrativo y que Ortiz aplica en momentos de especial intensidad dramática, como pueda ser el clímax de sus historias. Sin embargo, estos dos recursos expresivos que usa de forma común en ambos largometrajes, como se ha analizado, ya estaban muy presentes en los cortometrajes de la directora. 


\subsection{Introducción de un espacio onírico para explorar las emociones de los personajes.}

Desde su primer cortometraje, Paula Ortiz ha mostrado un especial interés en la representación de diferentes espacios oníricos. En El rostro de Ido la directora dedica una secuencia a representar una de las pesadillas de su protagonista, temeroso de perder el rostro, que se visualiza a sí mismo consumido por el fuego. Su personaje despierta asustado en medio de la noche, tras haber contemplado sus propios miedos. No es casual pues que en su última película, doce años después, la directora vuelva a incluir una pesadilla de su protagonista. En esta, la novia, en la noche de bodas, se despierta en la cama, tal y como sucediera con Ido, asustada tras ver una serie de imágenes fantasmagóricas. Algunas agradables, como el baile con Leonardo alrededor del fuego (que representa los deseos ocultos de la novia), otras terroríficas, como ella ahogándose bajo telas. Este espacio onírico se cuela en más secuencias gracias a la presencia del personaje de la anciana que aparece en numerosas ocasiones a lo largo de la historia. En Fotos de familia, las fotografías cobran vida, representando los sueños y deseos de su protagonista, trascendiendo al universo real que le rodea. Ortiz da vida a fotogramas estáticos, utilizando el espacio onírico para representar todo aquello que al protagonista le gustaría tener y no tiene. En El hueco de Tristán Boj, toda la representación de los títeres supone en sí misma un espacio onírico, simbólico, mediante el cual se visualiza una historia que no encuentra correspondencia directa en el universo diegético del titiritero y el niño.

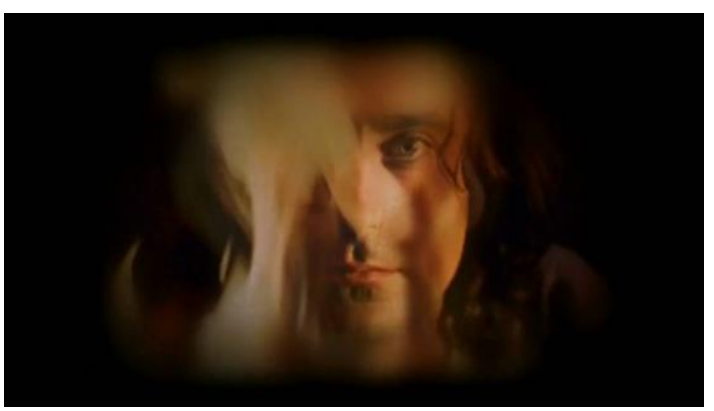

Fotograma 13. Espacio onírico en El rostro de Ido.

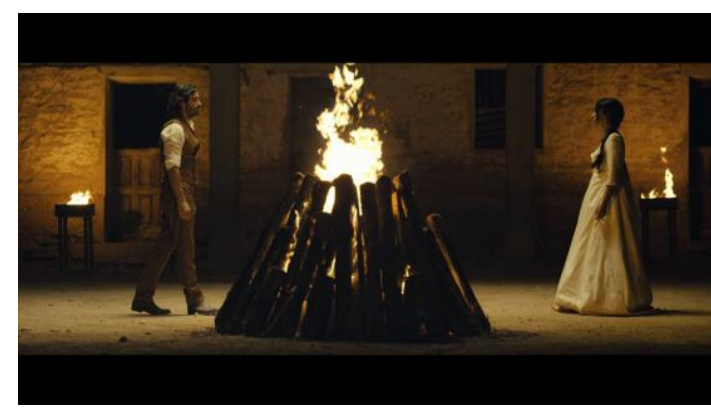

Fotograma 14. Espacio onírico en La novia.

\subsection{Búsqueda de lugares comunes: utilización del espejo y del entorno natural.}

Al igual que la repetición del espacio onírico en toda su obra, a lo largo de su breve trayectoria, Ortiz también ha mostrado un lugar común. Existe un elemento de puesta en escena al que la directora ha otorgado gran importancia tanto en sus tres cortometrajes, como en sus dos películas, de forma más o menos consciente. Este elemento son los espejos. En todas las producciones de Paula Ortiz, los personajes protagonistas terminan, tarde o temprano, frente a un espejo. Mirándose a sí mismos, recordando, echando de menos, notando la ausencia de aquello que les falta o, sencillamente, viendo su propio reflejo. Un elemento de la puesta en escena, al cual podemos considerar un "lugar común” dentro de su trayectoria, el cual también construye un estilo determinado en la directora. No parece casual pues, que en su primer cortometraje, El rostro de Ido, el espejo cobre tanta importancia. Pues la única forma que el personaje tiene de ver su rostro es mirándose frente a un espejo. Igualmente, en Fotos de familia, la primera vez que el espectador ve al personaje, lo hace viendo cómo este se engalana frente a un espejo, colocándose bien la pajarita. Posteriormente, el personaje se verá reflejado en el espejo cuando observe desde la distancia a la mujer que desea. En El bueco de Tristán Boj, el espejo aparece en el momento en el que la bailarina se queda sola, perdiendo al amor de su 
vida. En De tu ventana a la mía, la directora nos presenta a Luisa frente a un espejo. A lo largo de la historia se le verá en más de una ocasión acicalándose frente al espejo. En uno de los momentos más complejos para el personaje (cuando tiene que aceptar que perderá un pecho para salvar su vida del cáncer), Ortiz se decanta nuevamente por colocar al personaje frente a un espejo y enfrentar a este a su reflejo, estableciendo de esa manera un símil entre el antes y el después que, además, construye emocionalmente al personaje de Luisa. Al igual que con Luisa, Ortiz clausura el relato de Inés con esta junto a su hijo mirándose en otro espejo. En una secuencia anterior, se ve al mismo personaje mirando su vientre frente al mismo espejo. Un espejo que actúa como motor temporal, que devuelve a los personajes su reflejo a través del tiempo y que también ayuda a construir temporalmente la narración de los relatos de Ortiz. En La novia, Inma Cuesta tiene dos secuencias frente al espejo. Una primera en la que esta se mira a sí misma desnuda tras haberse quitado el vestido de novia y donde se le aparece la figura de la anciana tras de sí y una segunda, momentos antes de la boda, en la que el resto de chicas le ayudan a engalanarse para la ocasión. Nuevamente, el espejo actúa como contraste del personaje. Como se puede apreciar en los siguientes fotogramas, este "lugar común" está más que presente en toda la filmografía de la directora, no solo en sus largometrajes.
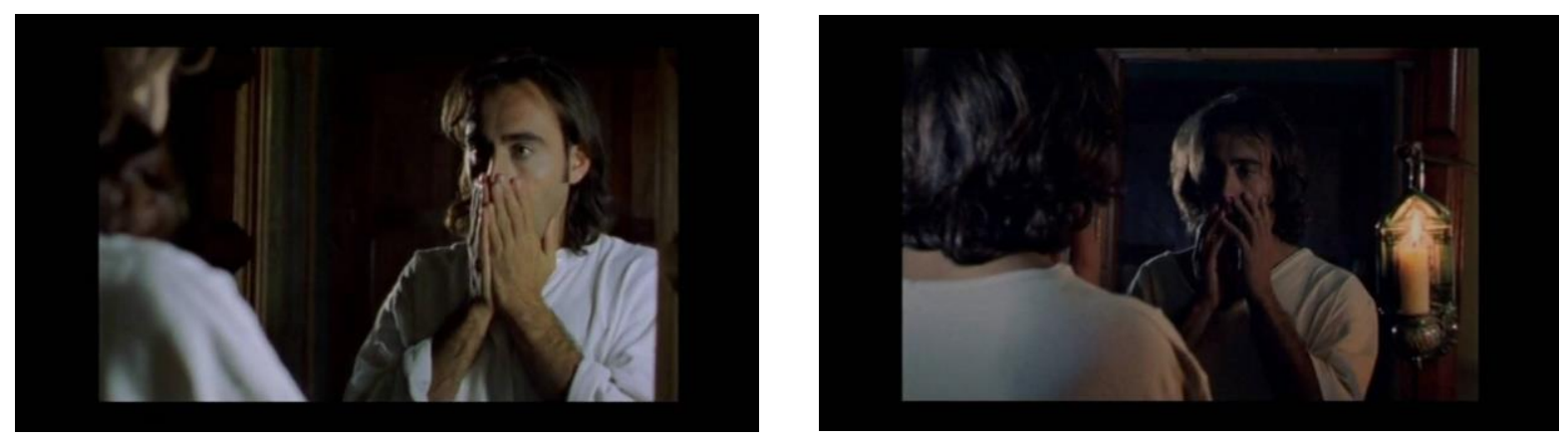

Fotogramas 15 y 16. El rostro de Ido.
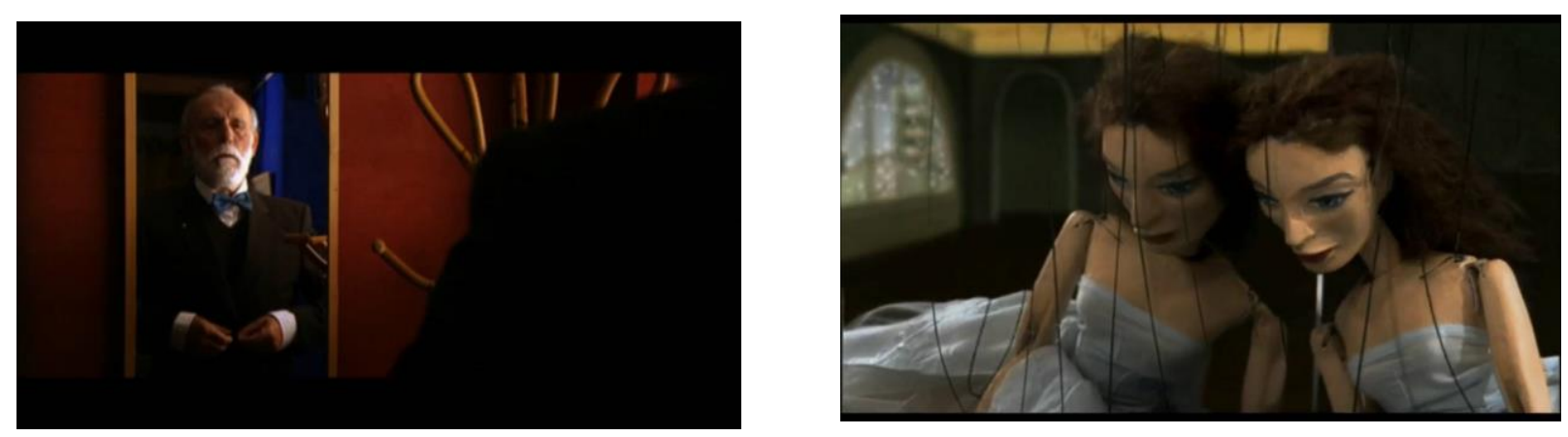

Fotograma 17. Fotos de familia.

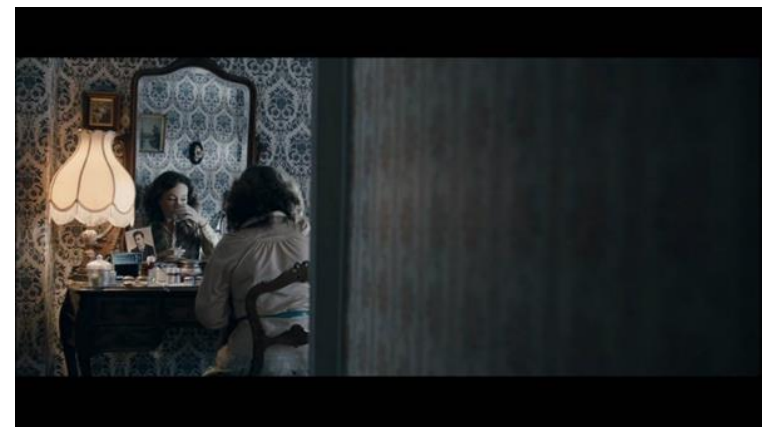

Fotograma 18. El hueco de Tristán Boj.

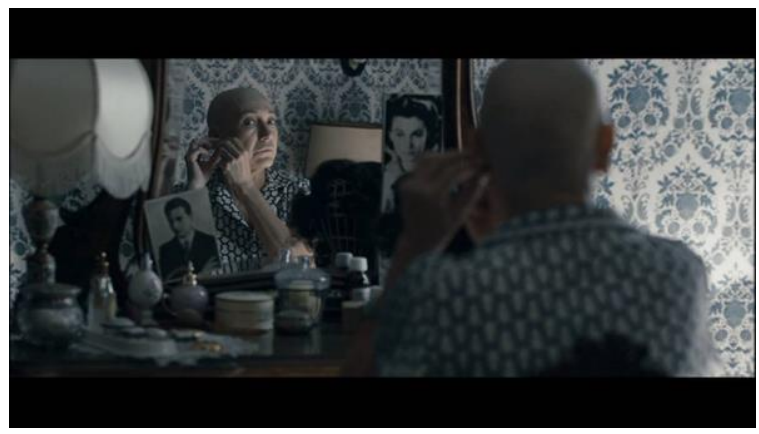

Fotograma 19. Luisa en De tu ventana a la mía.

Fotograma 20. Luisa en De tu ventana a la mía. 


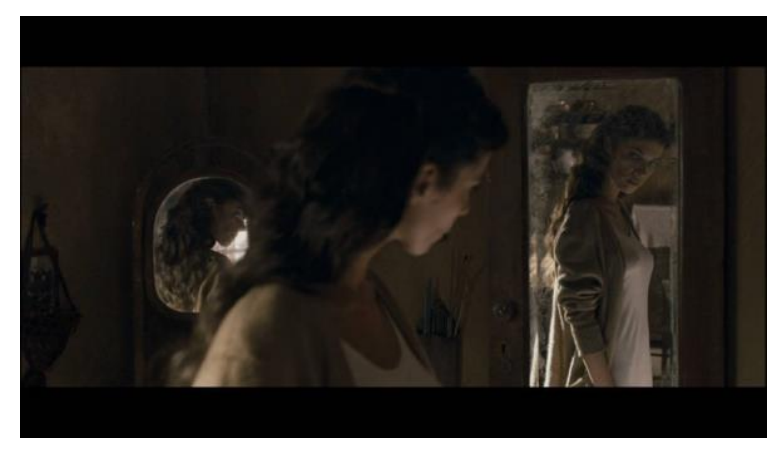

Fotograma 21. Inés en De tu ventana a la mía.

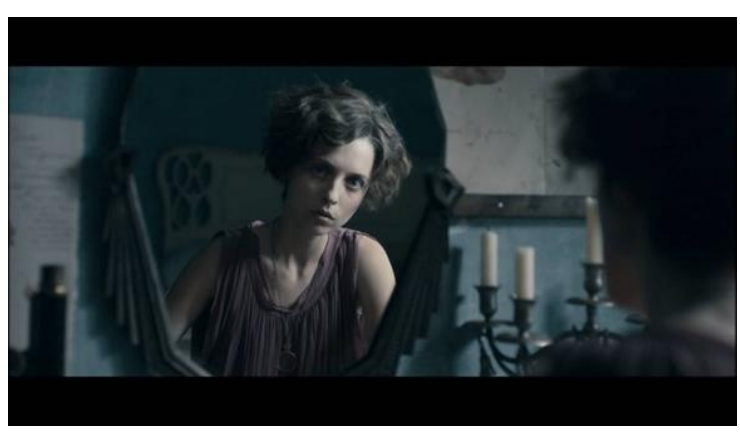

Fotograma 23. Violeta en De tu ventana a la mía.

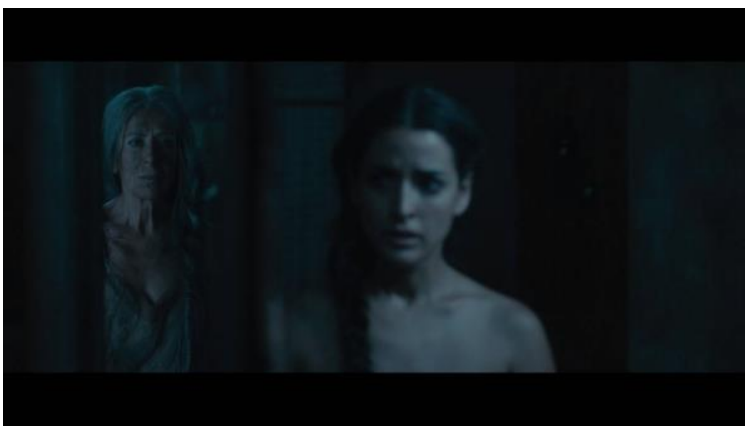

Fotograma 24. Inés en De tu ventana a la mía.

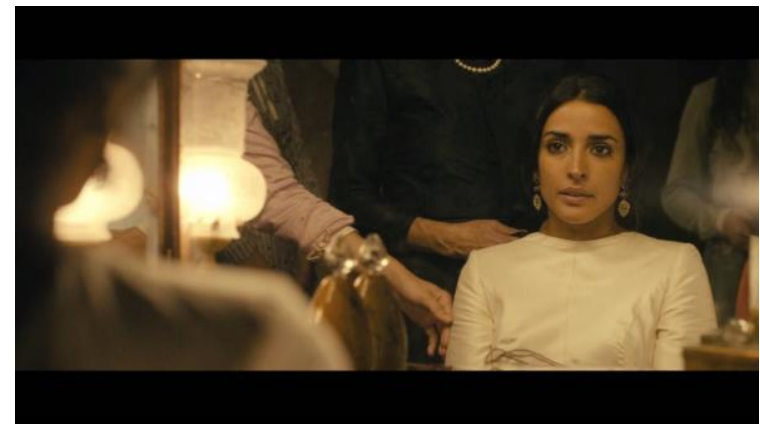

Fotogramas 25 y 26. La novia frente al espejo en La novia.

Esa búsqueda constante de lugares comunes que también conforma un estilo propio se extiende a la utilización de determinados recursos espaciales. Paula Ortiz ha mostrado un interés especial por integrar a sus personajes en espacios naturales (Inés en medio del campo en la siega, la novia en medio del agreste desierto, Violeta rodeada de plantas en un jardín botánico, etc.) o que, en su obra, existan ciertas clonaciones de elementos formales que se trasvasan de una película a otra. Sirvan de ejemplo en este caso, los sendos planos de apertura de sus dos largometrajes. Ambos con una estética similar. Ambos con un punto de vista determinado: el que otorga la mirada del plano cenital sobre sus personajes. Y ambos, con el mismo uso narrativo. Introducir al espectador en el prólogo de la película. No parece casual que Ortiz rodara el primer plano de su filmografía y el último que ha rodado hasta la fecha en la misma localización, configurando desde el mismo lugar natural dos espacios diferentes. Como si Ortiz volviera una y otra vez a imágenes que ya trabajó en sus cortometrajes, La novia finaliza con la anciana alejándose por el mismo desierto en el que Ortiz sentaba en El rostro de Ido a sus dos protagonistas en el primer plano de su filmografía. Todos estos elementos conforman la búsqueda de la directora de un "lugar común", de un estilo propio en sus largometrajes que, sin embargo, ya estaba muy presente en sus cortometrajes, integrando a sus personajes en espacios naturales, más o menos agrestes, según el carácter de sus personajes, que también otorgan un estilo determinado a la directora aragonesa. 


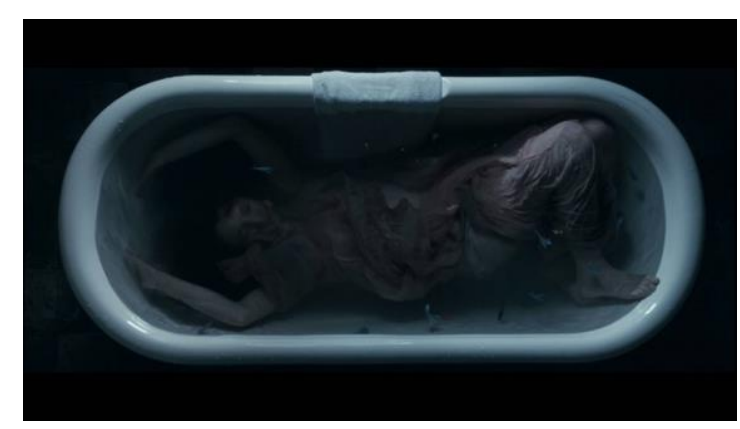

Fotograma 27. Primer plano de De tu ventana a la mía.

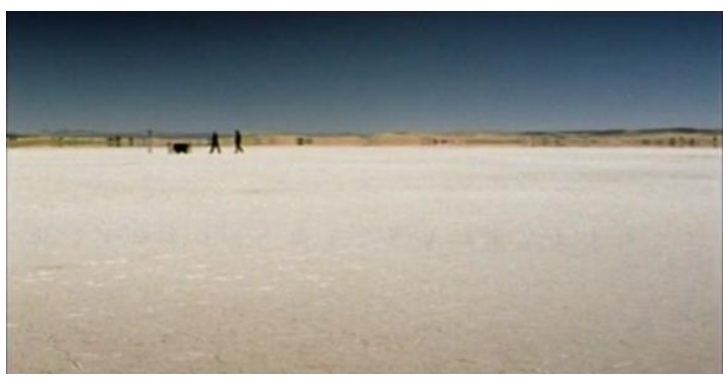

Fotograma 29 Primer plano de El rostro de Ido.

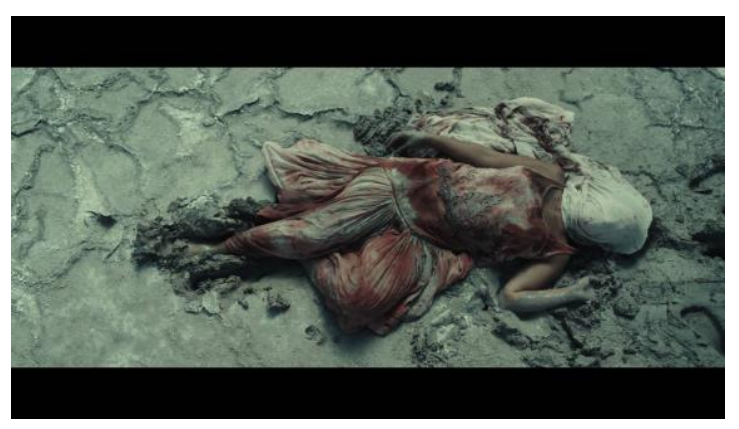

Fotograma 28. Primer plano de La novia.

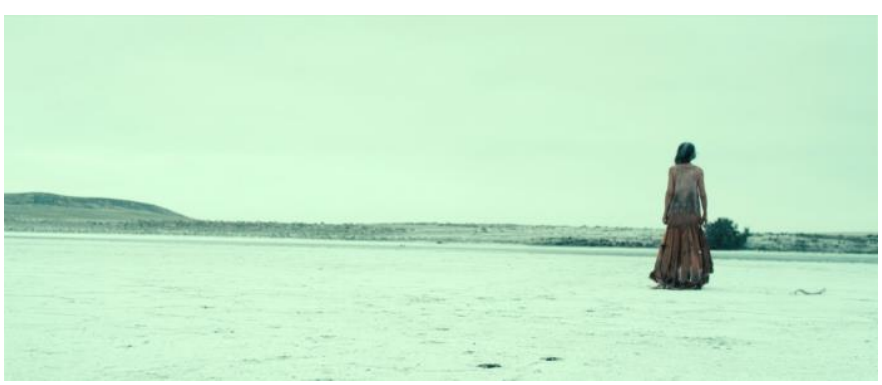

Fotograma 30. Último plano de La novia.

\section{Discusión y conclusiones}

Tras haber realizado el análisis fílmico de la obra de Paula Ortiz, y después de haber definido qué es cortometraje, cuáles son sus funciones narrativas y estéticas, se propone a partir de las siguientes conclusiones un debate que se pretende abrir desde este texto y que ojalá ayude a futuras investigaciones a prestar mayor atención al formato cortometraje, cuando se trate de analizar la obra de un director. Es necesario apostar por los análisis fílmicos en el ámbito del cortometraje, ya que nos aportan importantes claves para descubrir y determinar el estilo de los cineastas. Como se ha comprobado en el estudio del caso de Paula Ortiz, no existe problema alguno en aplicar las metodologías de los largometrajes a los cortometrajes de un director. Viendo el caso de la filmografía de Ortiz, donde se ha comprobado que existe un trasvase narrativo y estético de sus cortometrajes a sus largometrajes, que a su vez ha ido configurando un estilo propio en la directora aragonesa, se puede concluir lo siguiente, en relación a lo expuesto hasta el momento:

- Aunque existe un problema con la definición de cortometraje y sus funciones, es necesario concebir al cortometraje con una pieza con suficiente autonomía y fuerza (al margen de su fin). El cortometraje se presenta como un ensayo de temas recurrentes y un ejercicio de estilo.

- Rastreando a través del análisis fílmico, se pueden llegar a descubrir rasgos de estilo y, lo más importante, la búsqueda o revelación del ADN de un artista. En caso de que el director posea cortometrajes en su filmografía, hay que prestar atención a estos para ver si la configuración narrativa y estética que muestran un estilo determinado en un director, estaba ya presente en sus cortometrajes (como se ha visto en el caso analizado) o si, por el contrario, no ha existido un trasvase de elementos

- Es necesario un impulso en los estudios sobre los cortometrajes, que se distancien de la descripción industrial o de otros aspectos históricos y sociales. El cortometraje es generador de estilo, y se necesitan más estudios que profundicen en esta idea (especialmente aquellos que estudian las obras de cineastas). 
- En el ejemplo estudiado, se puede ver cómo los cortometrajes de Paula Ortiz marcan una tendencia sobre cómo se va a configurar el universo creativo de los largometrajes. No tiene por qué ser consciente, pero es una búsqueda constante. Tampoco tiene que vincularse a una fórmula de éxito determinada, sino a la reafirmación de un estilo propio.

- A pesar de las diferencias entre los cortometrajes y los largometrajes, en el caso estudiado se han encontrado estrategias narrativas y estéticas similares por parte de la cineasta, tal y como se ha visto en el análisis. Paula Ortiz apuesta por recurrir siempre a los mismos actores para dar vida a los personajes, por usar elementos narratológicos como el prólogo y el epílogo para iniciar y clausurar sus relatos, por importar elementos expresivos y narrativos propios del medio literario al medio cinematográfico, por representar el estado anímico de los personajes a través de los objetos, por usar de forma repetitiva recursos expresivos como la cámara lenta, las secuencias de montaje, o la potenciación del diseño sonoro, por introducir espacios oníricos en todas sus películas, así como por buscar de forma más o menos consciente lugares comunes como el personaje frente al espejo o el entorno natural que rodee a sus personajes. Estos elementos demuestran que existe un trasvase creativo, tanto de carácter narrativo, como de carácter estético, entre la trayectoria desarrollada en el formato cortometraje y la desarrollada a lo largo de dos largometrajes. Por lo que, en definitiva, nos invita a pensar que en el ámbito de la investigación, uno no debería limitarse por el formato a la hora de analizar el posible estilo de un director determinado, puesto que buena parte de la construcción de ese estilo puede que ya esté más o menos presente y visible en sus cortometrajes anteriores.

\section{Bibliografía}

AMPA (2016). Short film. Definitions. Los Angeles: AMPA.

Aumont, J. y Marie, M. (1988). Estética del cine: espacio fílmico, montaje, narración, lenguaje. Barcelona: Paidós.

Bardzinska, J. (2015): La doble vida de Kraysztof Kieslowski. Donostia: Filmoteca Vasca.

Bordwell, D. y Thompson, K. (1993). El arte cinematográfico. Barcelona: Paidós Ibérica.

Bresson, R. (1975). Notes sur le cinématographe. Paris: Gallimard.

Cantell, S. (2004). Poetry on screen or visualised jokes?. P.O.V., 18.

Carro, N. (1994). La vida en breve. Notas sobre el cortometraje mexicano. Dicine, 57.

Correa, J. (2007). El cortometraje en Colombia. Grandes actores. Cuadernos de Cine Colombiano. El cortometraje, 9.

Cousins, M. (2012). Historia del cine. Barcelona: Blume. 
Gómez, F. y Marzal, J. (2003). Una propuesta metodológica para el análisis del texto fílmico. En Actas del III Congreso de la Asociación Cultural Trama y Fondo. Madrid: Trama y fondo.

Hoffmann, H. (1981). Sprache des Kurafilms. Oberhausen: Schoningh.

Martin, M. (2002). El lenguaje del cine. Barcelona: Gedisa.

Meier, A. (2013). El cortometraje: el arte de narrar, emocionar y significar. México D.F.: Universidad Autónoma Metropolitana.

Real Academia Española de la Lengua (2014). Diccionario de la lengua española (vigésimo tercera edición). Madrid: Espasa

Sánchez-Noriega, J. L. (2002). Historia del cine. Madrid: Alianza Editorial.

Vanoye, F. y Goliot-Lété, A. (2008). Principios de análisis cinematográfico. Madrid: Adaba.

Velázquez, J. y Ramírez, L. (2000). Una década prodigiosa. El cortometraje español de los noventa. Alcalá de Henares: Festival de Cine de Alcalá de Henares-Comunidad de Madrid. 


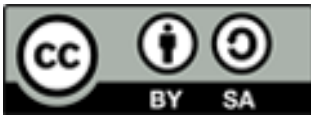

Licencia Creative Commons

Miguel Hernández Communication Journal

mhcj.es

\section{Forma de citar este artículo en las bibliografías}

Ignacio Lasierra Pinto y Joseba Bonaut Iriarte (2016): "Estrategias narrativas y estéticas en el paso del cortometraje al largometraje: análisis del caso de Paula Ortiz”, en Miguel Hernández Communication Journal, nº7, páginas 419 a 441. Universidad Miguel Hernández, UMH (Elche-Alicante). Recuperado el _ de

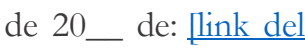
artículo en mhjournal.org] 